\title{
Physicians' Attitudes towards Euthanasia in Kuwait
}

\author{
Alia H. Gh. Askar ${ }^{a}$ Muneera Ben Nakhi ${ }^{b}$ Khadeijah Al-Rashidi ${ }^{b}$ \\ Bashayer A.M. Al-Musabbahie ${ }^{c}$ Nasra M. Shah $^{d}$ \\ aDepartment of Pediatrics, Mubarak Hospital, bDepartment of Obstetrics and Gynecology, \\ Maternity Hospital, 'Department of Surgery, Sabah Hospital, Ministry of Health, \\ dDepartment of Community Medicine, Faculty of Medicine, The Health Sciences Center, \\ Kuwait University, Kuwait
}

\section{Key Words}

Mercy killing · Euthanasia .

Physician-assisted suicide $\cdot$ Kuwait

\begin{abstract}
Objectives: The attitudes of physicians in Kuwait towards euthanasia were examined. An additional objective was to examine whether physician characteristics such as nationality, qualifications, years of experience and/or religion affect their attitude toward euthanasia. A comparison was also made between the experience of physicians who generally treat terminally ill patients and those who generally treat non-terminally ill patients in terms of attitudes toward hastening death to alleviate suffering. Methods: A descriptive study using a self-administered questionnaire was conducted among 228 physicians working in 5 selected government hospitals. The response was $92 \%$. Results: Nearly $92 \%$ of all
\end{abstract}

\begin{tabular}{ll}
\hline KARGER & ( ) 2001 S. Karger AG, Basel \\
1011-7571/00/0094-0268\$17.50/0 \\
$\begin{array}{l}\text { Eax + 41 61306 1234 kairger@karger.ch } \\
\text { www.karger.com }\end{array}$ & $\begin{array}{l}\text { Accessible online at: } \\
\text { www.karger.com/journals/mpp }\end{array}$
\end{tabular}

the respondents did not support the provision of means for terminally ill patients to commit suicide while $8 \%$ did. A majority favored providing pain killers and comfort even if this hastens the patient's death. About $20 \%$ of the physicians felt that the Ministry of Health should allow euthanasia under certain restricted conditions. About $47 \%$ of Hindu, $23 \%$ of Christian and $17 \%$ of Muslim physicians agreed to the legalization of euthanasia. Approximately $27 \%$ of physicians who were frequently exposed and $10 \%$ of those who were rarely exposed to terminally ill patients reported that they had been asked to hasten death. Physicians in Kuwait have not dealt with euthanasia as much as physicians in other countries such as Australia and are much less favorable towards it. Conclusion: The findings of this survey indicate that a minority of physicians in Kuwait believe that euthanasia should be legalized under certain conditions. Thus, there is a need for 
the medical community and the Ministry of Health to recognize and deal with this controversial topic.

Copyright $@ 2001$ S. Karger AG, Basel

\section{Introduction}

Although the primary focus of medical care is saving life and treating disease to enhance the quality of life, requests for medical practitioners to end life are not rare [1]. In recent years, euthanasia (or mercy killing) has received increasing attention, especially following the trial and conviction of a medical doctor, Dr. Kevorkian, who performed this practice in the state of Michigan, USA. Euthanasia has a variety of definitions, one of which describes it as 'a deliberate act undertaken by one person with the intention of ending the life of another person to relieve that person's suffering where the act is the cause of death' [2]. Another more specific definition describes euthanasia as 'taking active steps to end the life of another person, at that person's request, for what they see as their best interests' [1].

Euthanasia can be divided into three distinct types: active voluntary euthanasia (AVE), passive euthanasia and physician-assisted suicide. AVE covers the taking of active steps to hasten the death of another person, e.g. injection of a lethal dose or substance. In contrast, passive euthanasia refers to withdrawing or withholding life-sustaining treatment, e.g. switching off a respirator or discontinuing treatment. Physician-assisted suicide is defined as the act of intentionally killing oneself with the assistance of a physician who deliberately provides the knowledge or means, or both [1-3]. Even though active as well as passive euthanasia and physicianassisted suicide are sometimes mentioned separately in the literature, the word 'euthana- sia' is often used interchangeably to describe each of the above types [4].

Views concerning euthanasia vary from country to country. In a study of physicians done in Washington State, USA, it was found that $48 \%$ of the respondents agreed that euthanasia is never ethically justified, $42 \%$ disagreed with that statement, 54\% thought that euthanasia should be legal in some situations, but only $33 \%$ stated that they were willing to perform euthanasia [5]. Another study showed that many doctors who had practiced euthanasia mentioned that they would be most reluctant to do so again, and many respondents said that an emotional bond is required for euthanasia to be performed [6].

The practice of euthanasia and laws pertaining to it also vary between countries. In the Netherlands, Van der Maas et al. [6] reported that euthanasia is performed approximately 2,300 times per annum and assisted suicide about 400 times. Voluntary euthanasia was requested 3.5 times more often than assisted suicide [6]. In the USA on October 27, 1997, the state of Oregon passed the Death with Dignity Act, which legalized physician-assisted suicide [7]. In 1999, 27 patients committed physician-assisted suicide as a result of this Act. A study in Australia found that there is a relatively high level of support for and practice of AVE and physician-assisted suicide by medical practitioners in New South Wales [8].

Euthanasia in Kuwait is strictly prohibited by law (article 149/4: Criminal Law) and is forbidden under Islamic teaching (sourat AlMai'dah, verse 32, Holy Quran) [9]. To the best of our knowledge, no studies have been conducted in Kuwait and the Middle East concerning physicians' attitudes toward euthanasia. The overall objective of the present study was to examine the attitudes of physicians in Kuwait toward voluntary euthanasia. An additional objective was to determine 
whether physicians' characteristics such as nationality, qualifications, education or training abroad, number of years of working in Kuwait and religion affect their attitude toward voluntary euthanasia. A comparison was also made between physicians who generally treat terminally ill patients and those who generally treat non-terminally ill patients.

\section{Methodology}

A survey based on self-administered questionnaires was conducted among physicians working in 3 general hospitals and 2 specialty hospitals. Physician specialties were chosen to select doctors who were frequently exposed to terminally ill patients and those who were not. The Intensive Care Unit doctors, neurosurgeons, neurologists and all the doctors working in the Kuwait Cancer Center were considered those exposed to terminally ill patients. Dentists and radiologists were considered those less exposed to such patients. Our assumption about the exposure status of various types of physicians was validated through a question asked to physicians about the frequency with which they saw terminally ill patients.

A list of all physicians working in the selected hospitals and specialties who were on duty during December 1998 was obtained. This list excluded those who were on extended leave (study leave, maternal leave or other leave). The overall list comprised 249 physicians who were personally approached and requested to fill out the self-administered questionnaire. In most cases the questionnaire was left with the physician (or secretary) to be collected later. The physicians were given verbal and written assurance (on the questionnaire) that the information provided was strictly confidential and would be used only for academic purposes. The physicians were also assured that no identification information would be revealed to anyone. Finally, the physicians' names were not requested.

The questionnaire (appendix 1), had two main sections. The first section, composed of 10 questions, covered the physicians' characteristics. The second section elicited physicians' attitudes through 18 questions. Some of the questions were based on a questionnaire used in a study done by Baume and O'Malley [8] in Australia. The questionnaire was pre-tested on 10 doctors working in the Faculty of Medicine, Kuwait University, Kuwait.
All computations were performed using the SPSSPC/Windows statistical package. Data were entered and frequency tables for all variables were run. Distributions of all variables were tabulated and means of continuous variables were calculated with the corresponding standard deviation (SD). Cross-tabulations were run. For categorical variables, associations were tested using the $\chi^{2}$ test. Results were considered significant for a $\mathrm{p}$ value $<0.05$. In the case of $2 \times 2$ tables where the expected value for any of the cells was less than 5 , the $\chi^{2}$ test was replaced by Fisher's exact test.

\section{Results}

Of the 249 physicians approached, 228 completed and returned the questionnaire, yielding a response rate of $91.6 \%$. The high response rate was largely a result of the personal contact and request to fill out the questionnaire. Characteristics of the respondents are shown in table 1 . Of the 228 physicians who participated in the study, $72 \%$ were male. The average age of the respondents was 43.21 years $( \pm 9.07)$. About one fourth were Kuwaiti nationals and of the others, a majority had lived in Kuwait for 5 or more years.

A large majority (72\%) were Muslim. About 28\% had received their basic medical education from a European or an American university. Almost 95\% had received some postgraduate training.

Table 2 shows the attitudes of physicians regarding various questions related to euthanasia. Two questions were asked to ascertain opinions on relieving the suffering of the patient. About $56 \%$ agreed that pain medication should be given to relieve suffering even if this hastens the patient's death, while $71 \%$ agreed that providing comfort is the primary objective rather than prolonging the life of a terminally ill patient. A general question was asked as to whether or not it is sometimes right to provide the means for a patient to commit suicide. About $8 \%$ of the physicians agreed 
Table 1. Characteristics of the study population

\begin{tabular}{|c|c|c|}
\hline & Number & Percentage \\
\hline \multicolumn{3}{|l|}{ Sex } \\
\hline Male & 165 & 72.4 \\
\hline Female & 63 & 27.6 \\
\hline \multicolumn{3}{|l|}{ Age } \\
\hline $28-38$ years & 80 & 35.1 \\
\hline 39-47 years & 76 & 33.3 \\
\hline 48 years and older & 72 & 31.6 \\
\hline \multicolumn{3}{|l|}{ Nationality } \\
\hline Kuwaiti (always) & 60 & 26.3 \\
\hline Arab & 92 & 40.4 \\
\hline Asian & 38 & 16.7 \\
\hline European, American and others & 38 & 16.7 \\
\hline \multicolumn{3}{|l|}{ Years in Kuwait } \\
\hline Kuwaiti & 60 & 26.8 \\
\hline$<5$ & 59 & 26.3 \\
\hline $5-13$ & 52 & 23.1 \\
\hline 14 or more & 53 & 23.7 \\
\hline \multicolumn{3}{|l|}{ Religion } \\
\hline Muslim & 165 & 72.4 \\
\hline Christian & 47 & 20.6 \\
\hline Hindu/other & 16 & 7.0 \\
\hline \multicolumn{3}{|l|}{ Rank } \\
\hline Assistant registrar & 26 & 11.4 \\
\hline Registrar & 86 & 37.7 \\
\hline Senior registrar & 36 & 15.8 \\
\hline Consultant & 80 & 35.1 \\
\hline \multicolumn{3}{|l|}{ Years of professional experience } \\
\hline$<13$ years & 80 & 35.1 \\
\hline $14-21$ & 73 & 32.0 \\
\hline $22-43$ & 75 & 32.9 \\
\hline \multicolumn{3}{|l|}{ Place of basic medical education } \\
\hline Kuwait & 19 & 8.3 \\
\hline Arab countries & 108 & 47.4 \\
\hline Asian countries & 38 & 16.7 \\
\hline Europe, America and others & 63 & 27.6 \\
\hline \multicolumn{3}{|l|}{ Postgraduate training } \\
\hline Yes & 220 & 96.5 \\
\hline No & 8 & 3.5 \\
\hline \multicolumn{3}{|l|}{ Place of postgraduate training } \\
\hline Kuwait & 21 & 9.5 \\
\hline Arab countries & 65 & 29.3 \\
\hline Asian countries & 29 & 13.1 \\
\hline Europe, America and others & 107 & 48.2 \\
\hline
\end{tabular}


Table 3. The physicians' attitudes toward legalization of euthanasia

\begin{tabular}{lll}
\hline Questions & \multicolumn{2}{l}{ Physicians } \\
\cline { 2 - 3 } & $\mathrm{n}$ & $\%$ \\
\hline Total physicians & 228 & 100.0 \\
\hline
\end{tabular}

Whether the Netherlands situation should be introduced in Kuwait, i.e. legalization of euthanasia

$\begin{array}{lrr}\text { Yes } & 11 & 4.8 \\ \text { Maybe } & 42 & 18.4 \\ \text { No } & 175 & 76.8\end{array}$

Whether the Ministry of Health should approve euthanasia under certain conditions

$\begin{array}{lrr}\text { Yes } & 45 & 19.9 \\ \text { No } & 181 & 80.1\end{array}$

\begin{tabular}{lrr}
\hline How often does the physician wish & & \\
that euthanasia were legal in Kuwait & & \\
Often & 8 & 3.5 \\
Sometimes & 64 & 28.2 \\
Never & 155 & 68.2 \\
\hline
\end{tabular}

The physicians were reminded that euthanasia is legal in the Netherlands [10], and asked whether they thought the Netherlands' practice should be introduced in Kuwait (table 3). Only about 5\% agreed with introducing the Netherlands' practice in Kuwait and 18\% were unsure. When asked whether the physician himself/herself wished that euthanasia were legal in Kuwait, 68\% said never, 28\% said sometimes and $4 \%$ said that they often wished so. In answer to an open-ended question, 45 physicians (20\%) said the Ministry of Health should approve euthanasia for specific conditions such as metastasized cancer, intractable pain, brain stem death and multiorgan failure. Physicians' views regarding whether or not the Ministry of Health should approve euthanasia differed according to nationality and religion (table 4). Asians and Arabs appeared more favorable to approval by the Ministry of Health than others. Also, Hindu doctors favored it more than either

Table 4. Physicians' opinion on whether the Ministry of Health should approve euthanasia under certain restricted conditions by nationality and religion

\begin{tabular}{|c|c|c|c|c|c|c|}
\hline & \multicolumn{2}{|c|}{ Yes } & \multicolumn{2}{|l|}{ No } & \multicolumn{2}{|l|}{ Total } \\
\hline & $\mathrm{n}$ & $\%$ & $\mathrm{n}$ & $\%$ & $\mathrm{n}$ & $\%$ \\
\hline Total & 45 & 19.9 & 181 & 80.1 & $226^{1}$ & 100 \\
\hline \multicolumn{7}{|l|}{ Nationality } \\
\hline Kuwaiti & 17 & 28.8 & 42 & 71.2 & 59 & 100 \\
\hline Arab & 8 & 8.7 & 84 & 91.3 & 92 & 100 \\
\hline Asian & 15 & 40.7 & 22 & 59.9 & 37 & 100 \\
\hline European, American and others & 5 & 13.2 & 33 & 89.8 & 38 & 100 \\
\hline \multicolumn{7}{|c|}{ Statistics: $\chi^{2}=21.150 ;$ d.f. $=3 ;$ significance $=0.000$} \\
\hline \multicolumn{7}{|l|}{ Religion } \\
\hline Muslim & 27 & 16.6 & 136 & 83.4 & 163 & 100 \\
\hline Christian & 11 & 23.4 & 36 & 76.6 & 47 & 100 \\
\hline Hindu & 7 & 46.7 & 8 & 53.3 & 15 & 100 \\
\hline \multicolumn{7}{|c|}{ Statistics: $\chi^{2}=8.210 ;$ d.f. $=2 ;$ significance: $=0.016$} \\
\hline
\end{tabular}


Table 5. Whether the physician had ever been asked to hasten death, according to the frequency of exposure to terminally ill patients

\begin{tabular}{|c|c|c|c|c|}
\hline & \multicolumn{2}{|c|}{$\begin{array}{l}\text { Never/less } \\
\text { exposed }\end{array}$} & \multicolumn{2}{|c|}{$\begin{array}{l}\text { Frequently } \\
\text { exposed }\end{array}$} \\
\hline & $\mathrm{n}$ & $\%$ & $\mathrm{n}$ & $\%$ \\
\hline Total physicians & 155 & 100.0 & 73 & 100.0 \\
\hline \multicolumn{5}{|c|}{$\begin{array}{l}\text { Whether the physician had ever } \\
\text { been asked to hasten death }\end{array}$} \\
\hline Yes & 15 & 9.7 & 20 & 27.4 \\
\hline No & 140 & 90.3 & 53 & 72.6 \\
\hline \multicolumn{5}{|c|}{ Statistics: $\chi^{2}=11.992 ;$ d.f. $=1 ;$ significane $=0.001$} \\
\hline
\end{tabular}

Table 6. A comparison of the present study with the Western Australia study (percentage of affirmative answers)

\begin{tabular}{llr}
\hline Question & $\begin{array}{l}\text { Western } \\
\text { Australia } \\
\text { study }\end{array}$ & \\
& 93 & 78.4 \\
& 47 & 15.4 \\
Have you ever treated a terminally ill patient aged 12 years or over? & & \\
Has a patient ever asked you to hasten his/her death? & 75 & 57.5 \\
Faced with the request would you discuss it with: & 79 & 48.7 \\
$\quad$ Colleagues? & 64 & 24.1 \\
$\quad$ Relatives? & 33 & 41.7 \\
$\quad$ Nursing Staff? & 28 & 8.3 \\
$\quad$ A religious advisor? & 52 & 14.5 \\
Have you ever considered taking steps to bring about death? & 56 & 16.2 \\
Do other doctors sometimes practice AVE? & 59 & 4.8 \\
Do you think it's sometimes right for a doctor to provide the means & 58 & 19.7 \\
$\quad$ for a patient to commit suicide? & & \\
Should the Netherlands situation be introduced here'? & & \\
Should the law be changed to allow AVE? & & \\
\hline$\quad$ The word 'here' means the place where each study was conducted. & & \\
\hline
\end{tabular}

Christians or Muslims. Other characteristics such as years of experience and qualifications did not affect the respondents' attitudes significantly.

Pertaining to the physicians' own experience of a request for euthanasia, there was a significant difference between those who were frequently exposed to terminally ill patients and those who were less exposed or not ex- posed at all (table 5). Twenty-seven percent of the frequently exposed physicians had been asked to hasten death, compared to $10 \%$ of those who were less exposed. In terms of whether they had ever considered taking any steps to bring about a patient's death, $8 \%$ of the physicians said yes (table 6). In response to certain hypothetical situations that were presented, about one third of the physicians 
said that they might consider complying with a request for euthanasia in the case of a 69year-old man with a metastasized carcinoma who was no longer responding to treatment.

\section{Discussion}

Kuwait is a Muslim country where the practice of euthanasia is illegal and is contrary to religious beliefs. The Holy Quran states: 'For that cause that we decreed for the children of Israel that whoever killeth a human being for other than manslaughter or corruption on earth, it shall be as if he had killed all mankind' [11]. Yet there are situations in which about $8 \%$ of physicians in Kuwait believe that euthanasia is sometimes justifiable, and $28 \%$ sometimes wished it were legal (table 3).

The current legal position on euthanasia in Kuwait is as follows: Criminal Law 149 in Kuwait states that "whoever intentionally kills another person will be punished with a life sentence of prison and a fine of 15,000 (Kuwaiti Dinars) can be added'. This means that the perpetrator is punished for killing with a life sentence even if he had good intentions. This applies to voluntary euthanasia where the physician might act to relieve the patient's suffering. However, the judge has the right to evaluate the circumstances, look into the motives of the killer and thus have mercy on the accused during a sentence (Criminal Law 81) [12]. Thus, a doctor practicing euthanasia in Kuwait would ordinarily be judged as a criminal and the legal repercussions are likely to affect physicians' attitudes.

In consideration of the above religious and legal injunctions that are clearly against euthanasia, it was not surprising to find that only a small percentage of physicians condone the practice of euthanasia and only under restricted conditions. It was also not surpris- ing to find that physicians in Kuwait had dealt with the issue of euthanasia much less frequently than the Australian physicians studied by Baume and O'Malley [8]. Relatively stricter religious injunctions and lower exposure to terminally ill patients in Kuwait might largely explain differences between physicians practicing in the two countries.

A larger percentage of physicians in $\mathrm{Ku}-$ wait agreed with passive rather than active euthanasia (20 and $2 \%$, respectively). A possible reason for higher support of passive euthanasia may be the similarity between passive euthanasia and the termination of life support in the case of brain death, which is legal and is used in current practice. Another reason might be that in the case of passive euthanasia, the physician is not directly responsible for the patient's death. In the study by Steinberg et al. [1], similar findings were reported for Queensland, Australia, where 54\% of medical practitioners agreed with passive euthanasia and 36\% agreed with physicianassisted suicide.

The physician's role in Kuwait, as elsewhere, is regarded to be that of providing comfort and cure. A physician faced with a question of performing euthanasia is naturally presented with a conflicting situation in which the doctor can provide comfort only by ending the life of a patient. While only a few agreed that it might sometimes be ethical to provide the means to commit suicide, a fairly large percentage (56\%) agreed on giving pain medication to relieve suffering even if it hastens the patient's death.

Attitudes toward legalization differed significantly by nationality as well as religion. A smaller percentage of non-Kuwaiti Arab physicians felt that the Ministry of Health should legalize euthanasia under certain restricted conditions compared with Kuwaiti and Asian physicians. It is likely that the Arab expatriates did not want to reveal their attitudes 
about something that is known to be illegal. When compared according to religion, it was surprising to find that a larger percentage of Hindus approved of legalization of euthanasia, even though euthanasia is prohibited under Hindu religious teaching [13]. It is possible that the Hindu doctors in our sample were willing to express themselves more openly. However, we did not collect additional information such as whether or not the physician is currently practicing his/her religion actively.

Several of the physicians faced with the issue discussed the problem with other physicians and some with religious advisors. Several of the questions used in our study were the same as in a study by Baume and O'Malley [8], conducted in Western Australia. Table 6 shows a comparison of our findings with those from that study. Large differences were present in the attitudes of physicians from the two countries. A substantially lower percentage of doctors in Kuwait had been exposed to terminally ill patients, or been asked to hasten death. Only $8 \%$ of doctors in Kuwait had ever considered any steps to bring about death compared with $28 \%$ of Australian doctors. Also, only $16 \%$ of the Kuwaiti doctors compared to $56 \%$ of the Australian ones thought that it is sometimes ethical for a doctor to provide a patient the means to commit suicide. In terms of whether the Netherlands' practice should be introduced, only $5 \%$ of the Kuwaiti doctors agreed, compared with $59 \%$ of the Australian doctors. Discussion with nursing staff was reported by a much smaller percentage of Kuwaiti than Australian physicians, perhaps because nurses do not play an active role in decision making in the health care system in Kuwait and are not treated as part of the health care 'team'.

At present, euthanasia is not considered a major medical/legal issue in Kuwait. There is a lack of a forum within hospitals or the Ministry of Health where the physician who might be faced with an ethical dilemma may share his/her concerns. For some physicians, this may be a cause for psychological distress that deserves attention. The Ministry of Health needs to address this controversial issue, especially since Kuwait's demographic structure is changing and the life expectancy is now 76 years for females and 72 years for males [14]. As the population ages and life expectancy increases further, physicians are likely to encounter additional situations where the patient may request euthanasia. It is therefore important that the Ministry of Health and the medical community address this controversial issue and provide mechanisms to deal with it.

\section{Conclusion}

The major conclusion of this study is that euthanasia is an ethical concern for some physicians under some conditions in Kuwait. About one fifth of the physicians felt that the law should be changed to allow AVE. Several physicians seem to have been faced with situations in which they went through certain ethical dilemmas that might have pitted their religious beliefs and legal dictates that forbid euthanasia against their desire to provide comfort, especially in cases where they felt that it was futile to prolong life. Thus, there is a need for the medical community and the Ministry of Health to recognize and deal with this controversial issue.

\section{Acknowledgements}

We would like to thank Professor Peter Baume from the School of Community Medicine, University of New South Wales, for sharing his questionnaire with us. $\overline{276} \quad \overline{\text { Med Principles Pract 2000;9:268-281 }}$
Askar/Ben Nakhi/Al-Rashidi/ Al-Musabbahie/Shah 


\title{
APPENDIX
}

Kuwait University

Faculty of Medicine

serial no

\section{The Attitudes of Physicians Towards Euthanasia}

\begin{abstract}
Dear physician :
This questionnaire is part of a research by $6^{\text {th }}$ year medical student to assess your attitude

toward euthanasia ( mercy killing ). Your answers will be kept in the strictest confidence.

Please read the questions carefully and choose the answer that corresponds to your

opinion. Tick $\sqrt{ }$ in the box that you choose.
\end{abstract}

\section{Section A: Physician's characteristics}

1. Hospital

2. Department

3. Sex

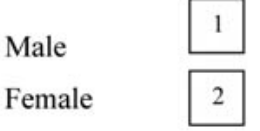

4. Age

5. Nationality

\begin{tabular}{l|l|} 
Kuwaiti & 1 \\
Arab & 2 \\
Asian & 3 \\
European, American, Others & 4 \\
\cline { 2 - 2 } &
\end{tabular}

6. If non-Kuwaiti, how many years have you been in Kuwait?

7. Religion

\begin{tabular}{l|l|} 
Muslim & 1 \\
Christian & 2 \\
Hindu & 3 \\
\hline Others & 4 \\
\hline
\end{tabular}

8. Rank

\begin{tabular}{|c|c|}
\hline Assistant Registrar & 1 \\
\hline Registrar & 2 \\
\hline Senior Registrar & 3 \\
\hline Consultant & 4 \\
\hline
\end{tabular}


9. Years of professional experience

10.Where did you complete your basic medical degree?

Kuwait

Arab countries

Asian countries

Europe, America, Others

\begin{tabular}{|l|}
\hline 1 \\
\hline 2 \\
\hline 3 \\
\hline 4 \\
\hline
\end{tabular}

11. Do you have any postgraduate training?

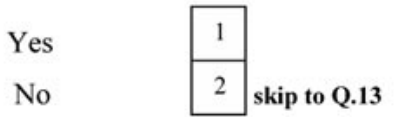

12. If yes, where did you receive your postgraduate training?

Kuwait

\begin{tabular}{|l|}
\hline 1 \\
\hline 2 \\
\hline 3 \\
\hline 4 \\
\hline
\end{tabular}

\section{Section B: Physician's attitude}

13. Have you ever treated terminally or chronically

\begin{tabular}{|c|c|}
\hline Never & \\
\hline Rarely & \\
\hline Sometimes 3 & \\
\hline Frequently & \\
\hline
\end{tabular}
ill patients aged 12 years or over?

Arab countries

Asian countries

Europe, America, Others

14. Has a patient ever asked you to hasten or speed up his / her death?

\begin{tabular}{l|l|} 
Yes & 1 \\
\cline { 2 - 2 } No & 2 \\
\hline
\end{tabular}

15. Faced with a request by a patient for speeding up death, would you discuss it with :

\begin{tabular}{|c|c|c|c|c|c|}
\hline \multirow[t]{2}{*}{ a- Colleagues } & Yes & 1 & \multirow[t]{2}{*}{ c- Relatives } & Yes & 1 \\
\hline & No & 2 & & No & 2 \\
\hline \multirow[t]{2}{*}{ b- Nursing staff } & Yes & 1 & \multicolumn{2}{|c|}{ d- A religious adviser Yes } & 1 \\
\hline & No & 2 & (e.g. priest, imam ) & No & 2 \\
\hline
\end{tabular}

16. Do you think it is sometimes right for a doctor Yes to provide the means for a patient to commit suicide? No 
17. Some physicians think that euthanasia may

sometimes be right. How do you feel about this ?

\begin{tabular}{|c|c|}
\hline & 1 \\
\hline & 2 \\
\hline $\begin{array}{l}\text { Agree } \\
\text { Neutral }\end{array}$ & 3 \\
\hline Disagree & 4 \\
\hline Strongly disagree & 5 \\
\hline
\end{tabular}

18. Is it appropriate to give pain medication to relieve suffering even if it hastens the patient's death?

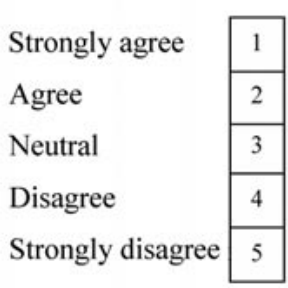

19. In treating terminally ill patients, is comfort the primary objective rather than prolonging the patient's life?

\begin{tabular}{l|c|}
\cline { 2 - 2 } Strongly agree & 1 \\
\cline { 2 - 2 } Agree & 2 \\
\cline { 2 - 2 } Neutral & 3 \\
\cline { 2 - 2 } Disagree & 4 \\
\cline { 2 - 2 } Strongly disagree & 5 \\
\cline { 2 - 2 } &
\end{tabular}

20. To the best of your knowledge, do other doctors sometimes take active steps to bring \begin{tabular}{l|l|} 
Yes & 1 \\
\cline { 2 - 2 } & No \\
\cline { 2 - 2 }
\end{tabular} about a patient's death ?

21. As you may know, euthanasia is legal in Netherlands. Should the Netherlands situation be introduced in Kuwait?

\begin{tabular}{l|l|} 
Yes & 1 \\
\cline { 2 - 2 } Maybe & 2 \\
\cline { 2 - 2 } No & 3 \\
\cline { 2 - 2 }
\end{tabular}

22. Should the Ministry of Health approve

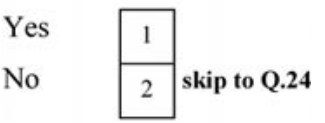
euthanasia under certain restricted conditions?

23. If yes, please specify those conditions: 
24. Suppose that euthanasia was legal. Now, consider the following 3 situations. Select your preferred option regarding euthanasia:

a- A 65 years-old patient with mild stroke and minor neurologic damage requests euthanasia. Would you comply?

Yes Maybe

No

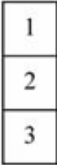

b- A formally active 24-years-old patient has $3^{\text {rd }}$ degree burns over $68 \%$ of his body from a car explosion 6 months earlier. He must undergo painful daily treatments and requests euthanasia. Would you comply?

c- A man aged 69 years with a metastasized bronchial Yes carcinoma who is no longer responding to treatment Maybe requests euthanasia. Would you comply?
Yes

Maybe

No

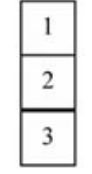

No

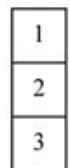

25. There are 3 types of euthanasia, as listed below. Do you approve or disapprove of each one? (select the category that is closest to your opinion )

A. Active euthanasia ( $=$ action such as giving the patient an injection of medication sufficient to cause death ).

\begin{tabular}{l|c|}
\cline { 2 - 2 } Strongly approve & 1 \\
\cline { 2 - 2 } Approve & 2 \\
$\begin{array}{l}\text { Neutral } \\
\text { Disapprove }\end{array}$ & 3 \\
\cline { 2 - 2 } Strongly disapprove & 5 \\
\cline { 2 - 2 } &
\end{tabular}

B. Passive euthanasia ( $=$ on patient's request, withdrawing or withholding of life-sustaining treatment, e.g. switching off respirator or discontinuing treatment).

Strongly approve

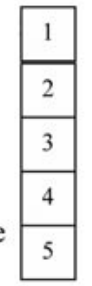

C. Physician assisted suicide ( = giving a patien advise about how to commit suicide, for example giving a prescription

Approve

Neutral

Disapprove

Strongly disapprove

$$
\begin{array}{|l|}
\hline \\
\hline 2 \\
\hline 3 \\
\hline 4 \\
\hline 5 \\
\hline
\end{array}
$$
of medication to use for suicide).

\begin{tabular}{|c|c|}
\hline Strongly approve & 1 \\
\hline Approve & 2 \\
\hline Neutral & 3 \\
\hline Disapprove & 4 \\
\hline Strongly disapprove & 5 \\
\hline
\end{tabular}


26 . When you see a chronically or terminally

27. According to your religion, is euthanasia :

\begin{tabular}{l|l|}
\cline { 2 - 2 } Approved & 1 \\
\cline { 2 - 2 } Approved under certain conditions & 2 \\
\cline { 2 - 2 } Prohibited completely & 3 \\
\cline { 2 - 2 } Don't know & 4 \\
\hline
\end{tabular}

28. Have you ever considered taking any steps to bring about a patient's death?

THANK YOU FOR YOUR CO-OPERATION

\section{References}

1 Steinberg M, Najman J, Cartwright C, MacDonald S, Williams G: Endof-life decision-making: Community and medical practitioners' perspectives. Med J Aust 1997;166: 131-135.

2 Lavery J, Dickens B, Boyle J, Singer $\mathrm{P}$ : Euthanasia and assisted suicide. Can Med Assoc J 1997;156:14051408 .

3 Baume P, O'Malley E, Bauman A: Professed religious affiliation and the practice of euthanasia. $\mathrm{J}$ Med Ethics 1995;21:49-54.

4 Anonymous: Euthanasia: Answers to frequently asked questions. IAETF (International Anti-Euthanasia Task Force) accessed on 12 November 1998, http://www.iaetf. org/fag.htm.

5 Cohen JS, Fihn SD, Boyko EJ, Jonsen AR, Wood RW: Attitudes toward assisted suicide and euthana- sia among physicians in Washington State. N Engl J Med 1994;331:8994.

6 Van der Maas PJ, Van Delden JJM, Pijenbor L, Looman CWIV: Euthanasia and other medical decisions concerning the end of life. Lancet 1991;338:669-674.

7 Sullivan AD, Hedberg K, Flemming DW: Legalized physician-assisted suicide in Oregon - the second year. N Engl J Med 2000;342:598-604.

8 Baume P, O'Malley E: Euthanasia: Attitudes and practices of medical practitioners. Med J Aust 1994;161: 140-144.

9 Al-Attiqi SA: Adab Mehnat Al-Teb Wa Ahkamuha Al-Shareyia (in Arabic). Kuwait, Kuwait Medical Association, 1995, pp 59-60.
10 Van Der Wal G, Van Eijk JThM, Leenen HJJ, Spreeuwenberg C: Euthanasia and assisted suicide. 1. How often is it practiced by family doctors in the Netherlands? Fam Pract 1992;9:130-134.

11 Pickthall MM: The Meaning of the Glorious Koran: An Explanatory Translation. New York, Mentor Books, 1977, p 99.

12 Al-Nasrallah F: Sharh al-Kawaed Al-Aamah Le-Kanoon Al-Jaza’a alKuwaiti (in Arabic). Kuwait, Dar alkotob le-al-teba'ah wa al-tawzeea, 1996-1997, vol 1, pp 240-241.

13 Keown D, Keown J: Killing, karma and caring: Euthanasia in Buddhism and Christianity. J Med Ethics 1995;21:265-269.

14 Moussa M, Al-Sayed A: Mortality in Kuwait: Pattern and seasonality. Med Principles Pract 1998;7:1827. 